\title{
Mineral Oil versus Vegetable Oil as Electroinsulating Fluids in Contact with Coating Lacquers \\ A thermochemical stability study
}

\author{
IOSIF LINGVAY ${ }^{1}$, GABRIELA CIRCIUMARU ${ }^{1}$, ANDREEA VOINA ${ }^{1}$, ADRIANA-MARIANA BORȘ ${ }^{2 *}$ \\ 1.ICPE SA, 313 Splaiul Unirii, 030138, Bucharest, Romania \\ 2. National Institute for Research and Development in Electrical Engineering INCDIE ICPE-CA, 313 Splaiul Unirii, 030138, Bucharest, Romania
}

The thermochemical stability of a MOL (mineral oil) electroinsulating mineral oil was studied by the gas chromatography technique, compared with a Voil (vegetable oil) electroinsulating fluid based on natural esters (oil), exposed to a longer (1000 hours) thermal treatment $\left(110 \pm 5^{\circ} \mathrm{C}\right.$ ) in contact with the core transformer plate (silicon steel sheet) both blank and covered by immersion with three different types of lacquers ( $L-G$ epoxide, L-528 alkyl epoxy-melamine copolymer and L-S polyurethane). Experimentally it was noted that during the thermal treatment applied and in contact with the silicon steel sheet, the investigated oils have produced mainly $\mathrm{C}_{2} \mathrm{H}_{4}, \mathrm{CH}_{4}$ and $\mathrm{H}_{2}$. The total amount of flammable gases formed in Voil (vegetable oil) is about 7.5 time lower than in MOL. It has also been found that the lacquer coating of the silicon steel sheet does not change the mechanism of gas formation processes in the investigated oils, as well as the fact that the oxygen content of the investigated oils decreases monotonously during the thermal treatment applied due to either the formation of $\mathrm{CO}_{2}$ and $\mathrm{CO}$ and the oxidation processes of investigated lacquers.

Keywords: transformers, mineral oil, vegetal oil, gas formation, coating lacquers

In sustainable development perspective, the continuous and secure supply of electricity to consumers of all categories (domestic, hospital, industrial, etc.) is a priority issue.

Safety in operation of installations and equipment for the transmission and distribution of electricity is largely determined by the functional characteristics degradation (ageing) of the materials used to make them.

Materials ageing of the electrical installations and equipment is due to the concerted and synergistic action of several stress factors (chemical, electrical, mechanical, microbiological, etc.) specific to the operating environment.

The power transformers are indispensable to the power system. In their construction there are a number of materials, such as silicon steel sheet, copper conductors, Kraft insulating paper, electroinsulating fluid (transformer oil), etc., materials that operate under the synergic action of stress factors [1]:

- electric power (working voltage and frequency);

- chemical (interactions of the insulating fluid and it components - compounds with sulphur [2-4], dissolved oxygen [5] etc., with solid components (steel, copper [5, 6], Kraft paper [7, 8] polymeric films [8-12], etc.), and

- mechanical (mechanical stresses, magnetic circuit shocks, etc.).

The result consists in significant changes of the functional characteristics which, in the absence of efficient and functional protection systems, can lead to damage to power transformers with special material and social implications and a harmful impact on environmental factors (Figure 1), [13, 14].
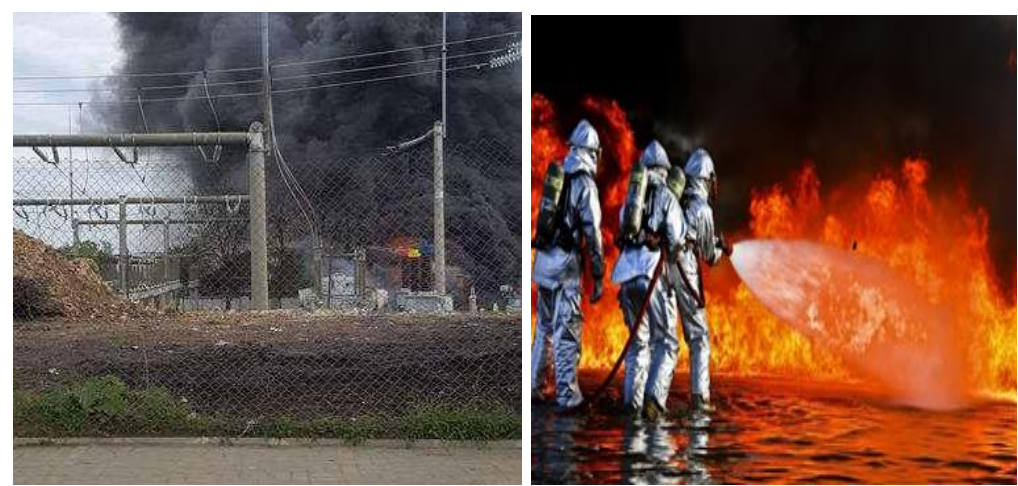

Fig. 1. Explosion and simultaneous fire of three power transformers in Botoșani city, RO $[13,14]$ - soil / surface water pollution by drain about 10 tons of mineral oil and air pollution by burning about 11 tons of oil

*email: adrianambors@gmail.com,Phone:0773917319 
During power transformers operation, under the synergic action of electrical, thermal and chemical stress factors (due to interactions between the electroinsulating fluid and Kraft paper in the presence of oxygen dissolved in oil), the electroinsulating fluid and Kraft degraded paper produce gases [15-18] and furanic compounds [19-22] which are persistent toxic products with harmful impact on the quality of environmental factors [23-29].

Recent studies [30-35] showed that the formation of gases (including flammable) and furan products is substantially lower when electroinsulating fluids based on natural esters (vegetal oils) are used comparing to the use of the traditional oils of transformer based on mineral oil. This way, the risk of events (such as those illustrated in Figure $1[14,15])$ is significantly reduced.

In different electrical applications, including the contact with electroinsulating fluids, coatings and / or impregnation lacquers are often used [36, 37]. In view of these considerations, the paper purpose is to determine the flammable gases formed in a mineral electroinsulating fluid as compared to a vegetal oil that is in contact with three different types of electroinsulating lacquers used.

\section{Experimental part}

In 0.5 L Erlenmeyer flasks with ground glass joint and glass stopper were introduced about $400 \mathrm{~mL}$ oil in which silicone steel sheets (strips of $15 \times 100 \mathrm{~mm}$, \# $0.2 \mathrm{~mm}$ - total surface $60 \mathrm{~cm}^{2}$ ) was immersed blank or covered by immersion with investigated lacquers $(\sim$ about $0.03 \mathrm{~mm}$ ). After the excess lacquer has drained, silicon steel sheets have been exposed to a thermal treatment for 3 hours at $160 \pm 5{ }^{\circ} \mathrm{C}$ for lacquer film polymerization. The Erlenmeyer flasks with the prepared samples were exposed to thermal treatment at $110 \pm 5^{\circ} \mathrm{C}$ in a France Etuve $980 \mathrm{XL}$ type thermostatic oven.

Initially and periodically from 7 to 7 days of heat treatment, oil samples were taken in order to determine the gas content with a chromatograph gas manufactured by Perkin Elmer 600 CLARUS (US).

The measurements were performed for both electroinsulating fluid based on MOL mineral oil (usually used in transformers) of origin [43] and Voil (vegetal oil) used for electrical applications [44]. The investigated lacquers are shown in Table 1.

Table 1

TYPES OF INVESTIGATED LACQUERS [36, 37]

\begin{tabular}{|l|l|l|ll|}
\hline Sample Cod & Type of lacquer & \multicolumn{1}{|c|}{ Structure } & \multicolumn{2}{|c|}{ Solvent } \\
\hline $\boldsymbol{L}-\mathbf{5 2 8}$ & 528 EZ [45] & $\begin{array}{l}\text { monocomponent alkyl-epoxy- } \\
\text { melamine }\end{array}$ & $\begin{array}{l}\text { Thinner 528 EZ - a mixture of aromatic } \\
\text { hydrocarbons and alcohols }\end{array}$ \\
\hline $\boldsymbol{L}-\boldsymbol{G}$ & ROPOXID 501 [46] & bicomponent - epoxy & Acetone & $\begin{array}{l}\text { Thinner 21-06 a mixture of aromatic } \\
\text { hydrocarbons and alcohols }\end{array}$ \\
\hline $\boldsymbol{L}-\boldsymbol{S}$ & $\begin{array}{l}\text { SIGMADUR } \\
\text { CLEARCOAT [47] }\end{array}$ & bicomponent - polyurethane \\
\hline
\end{tabular}

\section{Results and discussion}

The gas formation evolution during thermal treatment applied at $110 \pm 50{ }^{\circ} \mathrm{C}$ in the $M O L$ mineral electroinsulating fluid in contact with a silicon steel sheet is shown in Figure 2.

Comparative, Figure 3 shows the evolution of gas formation in the Voil (vegetal oil) exposed to the same treatment.

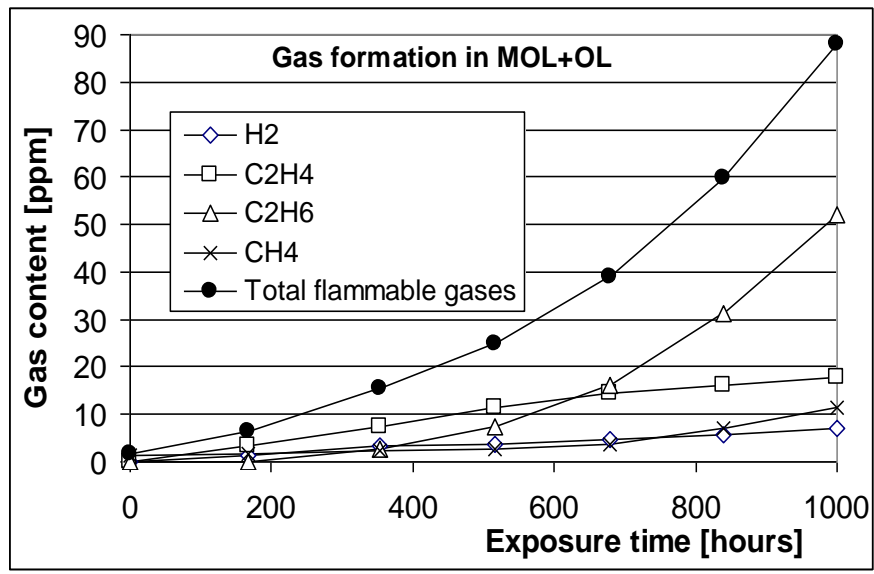

Fig. 2. Formation of flammable gases in MOL (mineral oil) 


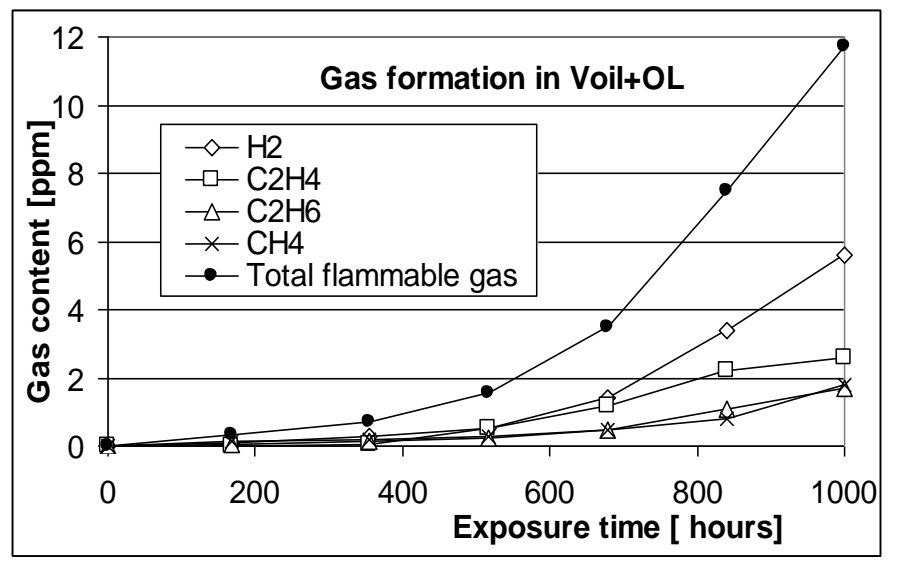

Fig. 3. Formation of flammable gases in Voil (vegetal oil)

By comparing Figures 2 and 3 one can observe that during the thermal treatment applied $\left(110 \pm 50{ }^{\circ} \mathrm{C}\right)$ and in contact with the silicon steel sheet, immersed in the types of oils investigated, after the aliphatic chain breaks, $\mathrm{C}_{2} \mathrm{H}_{4}$, $\mathrm{CH}_{4}$ and $\mathrm{H}_{2}$ are formed before other flammable gases.

It is also noted that, the total amount of gases formed in Voil (vegetable oil) is about 7.5 times less than in the mineral oil MOL (mineral oil), which is in accordance with $[15,17,22,38]$ and indicates a higher thermochemical stability of Voil (vegetal oil) [39-42].

Figure 4 shows the evolution of flammable gas volumes (in $\mathrm{L} / \mathrm{kg}$ of oil) in the $M O L$ and Voil oils at $110 \pm 50{ }^{\circ} \mathrm{C}$, with silicon steel sheet coated with three different types of lacquer: $L-G$ epoxide, $L-528$ alkyl-epoxy-melamine copolymer and $L-S$ polyurethane.

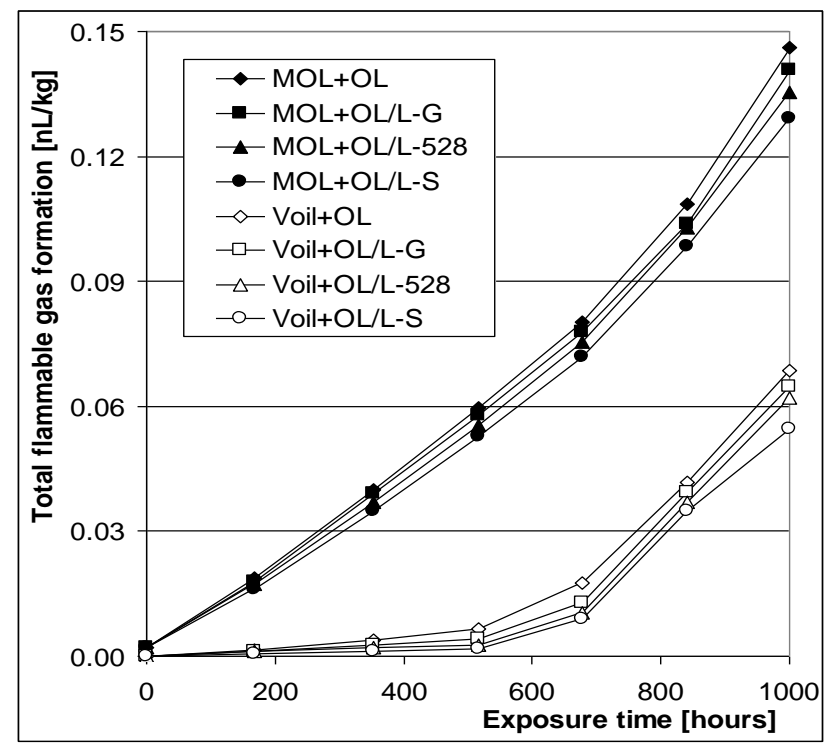

Fig. 4. Comparative evolutions of flammable gases in the MOL and Voil in contact at $110 \pm 5^{\circ} \mathrm{C}$, with silicon steel sheet (OL) uncovered and covered with investigated lacquers (OL/L-G, OL/ L-528 or OL/L-S)

Analyzing Figure 4 is noted that the total volume of flammable gases formed during the 1000 hours of thermal treatment applied at $110 \pm 5{ }^{\circ} \mathrm{C}$ in $M O L$ is about 2 times higher than in the case of Voil. It is also noted that coating with lacquer a silicon steel sheet does not change the mechanisms of gas formation in oils, which shows that the gas formation is the result of successive processes that are produced by free radicals whose formation is not influenced by silicon steel sheet.

In this context, by comparing the trend of flammable gas formation in $M O L$ and Voil, it is observed that the process at $110 \pm 5^{\circ} \mathrm{C}$ in $M O L$ evolves linearly in the first 700 hours of thermal treatment followed by an acceleration of the process.

When Voil, was used the gases formation required a starting time of about 550 hours, showing that in this case the activation energy associated with the free radical formation process is substantially higher than in the case of $M O L$ use. 
The fact that, in both case of using $M O L$ and Voil the formed gases volume decreases due to the silicon steel sheet coating with the investigated lacquers (the decrease being influenced by the lake type) shows that, during the thermal treatment applied, the lacquers consume the reactant (e.g. the dissolved oxygen) which influences the kinetics of gas formation in oil. A similar finding was reported in [8-11] for paints used for the inner protection of transformer tanks.

Figures 5 and 6 shows the dissolved oxygen content evolution of the investigated oils

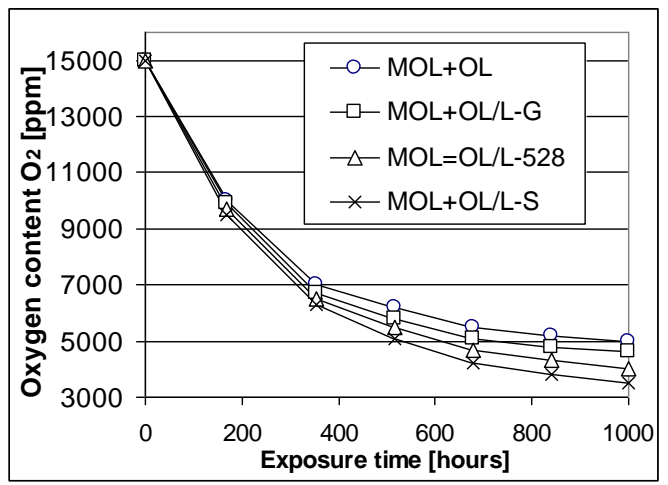

Fig. 5. Oxygen content evolution of MOL during thermal treatment applied in contact with silicon steel sheet (OL) uncovered and covered with investigated lacquers $(\mathrm{OL} / \mathrm{L}-\mathrm{G}, \mathrm{OL} / \mathrm{L}-528$ or OL/ L-S)

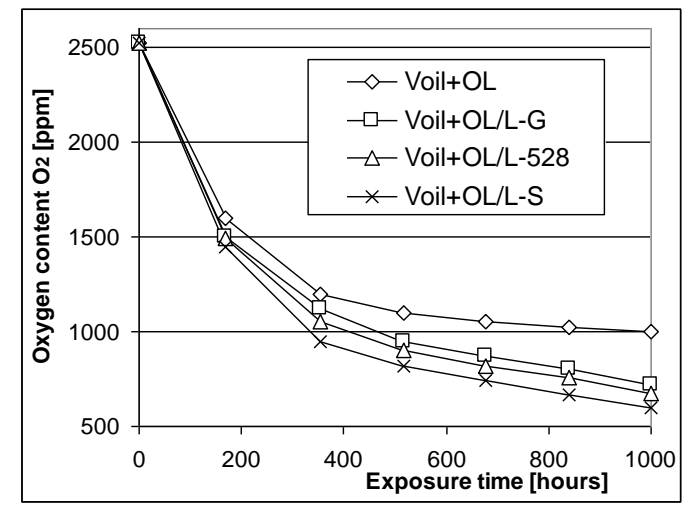

Fig. 6. Oxygen content evolution of Voil during thermal treatment in contact with silicon steel sheet (OL) uncovered and covered with investigated lacquers (OL/L-G, OL/L-528 or OL/ L-S)

By comparative analysis of the Figures 5 and 6 , one can conclude that the solubility of atmospheric oxygen in $M O L$ (mineral oil) is about 6 times higher than in Voil.

It is also noted that during the thermal treatment applied, the oxygen content in the investigated oils decreases. This fact can be due to oxygenation reactions of the oils and / or lacquers investigated.

Oxygen content in the oil is influenced by the presence and type of the lacquer in system, which during the thermal treatment applied to the lacquers undergoes thermal oxidation processes. Thus, there is a reduction in the thermooxidative stress on the oil (antioxidant effect) and in the oil oxygen content.

In order to assess the antioxidant effect of investigated lacquers the evolution during the thermal treatment applied of the $\mathrm{CO}_{2}$ and $\mathrm{CO}$ content in the $M O L$ and the Voil was determined and compared. The results are shown in Figures 7 and 8.

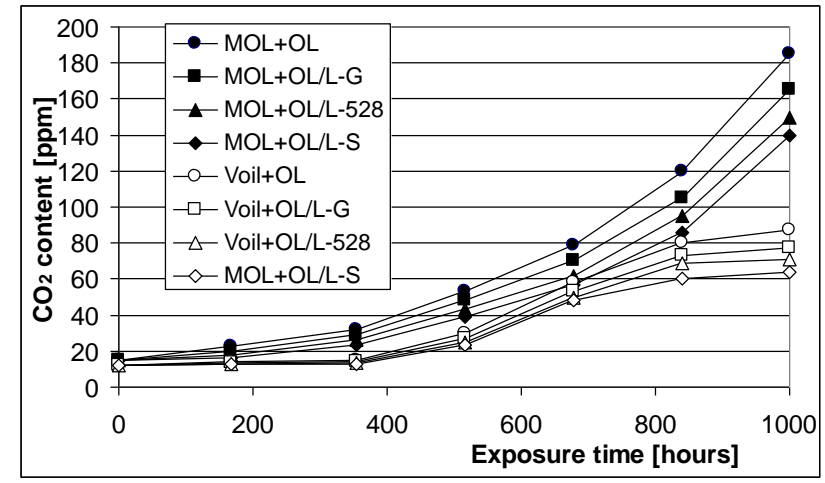

Fig.7. Evolution during the thermal treatment applied of the $\mathrm{CO}_{2}$ content in the investigated oil samples 
Analysing Figure 7 is noted that the initial $\mathrm{CO}_{2}$ content in the investigated oils is equal to $15 \mathrm{ppm}$ in the $M O L$ and $12 \mathrm{ppm}$ in the Voil. It can be observed that the $\mathrm{CO}_{2}$ formation in $M O L$ shows a continuous increases trend without kinetic limitation, which can be explained by the relative high content of oxygen (over $3000 \mathrm{ppm}$ after 1000 hours of thermal treatment - Figure 5).

Comparing Figures 5 and 7 one can affirm that the $\mathrm{CO}_{2}$ formation in the presence of lacquers investigated is directly related to the $M O L$ oxygen content, which decreases monotonous either by the $\mathrm{CO}_{2}$ (Figure 7) and $\mathrm{CO}$ formation (Figure 8), or through the investigated lacquers oxidation processes.

In Figure 7 it is observed that the forming process of $\mathrm{CO}_{2}$ in the Voil during the thermal treatment applied, requires a start period of about 400 hours after which up to about 700 hours there is an exponential acceleration, and over 700 hours there is a kinetic limitation of the process, which is probably explained by the decrease in oxygen content to less than 1000 ppm (Figure 6).

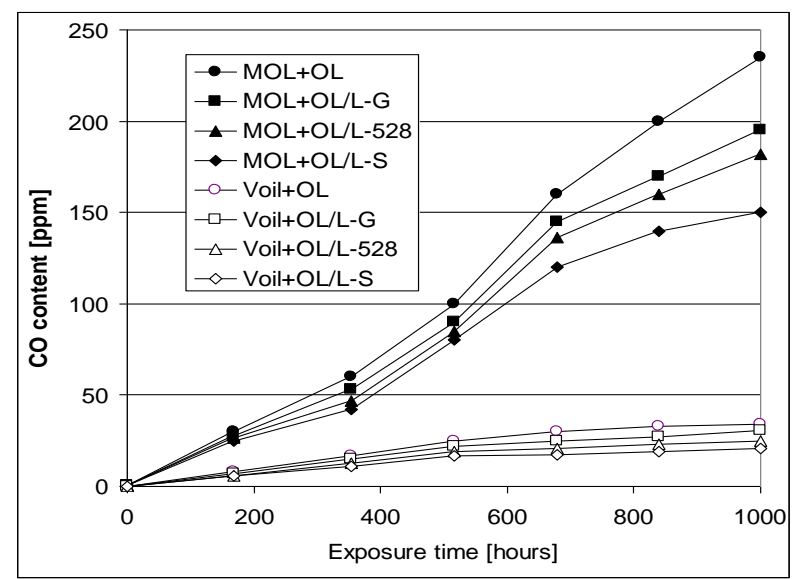

Fig. 8. Evolution during the thermal treatment applied to the $\mathrm{CO}$ content of the investigated oil samples

Analysing Figure 8 one can see that the $\mathrm{CO}$ formation in $M O L$ is much more pronounced than in the Voil (after1000 hours of thermal treatment, almost 10 times higher) showing a higher thermochemical stability of the Voil.

\section{Conclusions}

The thermochemical stability of a $M O L$ mineral insulating fluid was studied by the chromatography gas technique. It was compared to an electroinsulation fluid based on natural esters, Voil (vegetal oil) exposed to a thermal treatment $\left(110 \pm 5^{\circ} \mathrm{C}\right)$ extended (1000 hours) in contact with a transformer core plate (silicon steel sheet) both blank and immersed (about $30 \mu \mathrm{m}$ ) in three different types of lacquers ( $L-G$ epoxide, $L-528$ alkyl epoxy-melamine copolymer and $L-S$ polyurethane).

Experimental dates have shown the following:

$>$ during the thermal treatment applied and in contact with the silicon steel sheet immersed in the investigated oils, the follwing main products are formed: $\mathrm{C}_{2} \mathrm{H}_{4}, \mathrm{CH}_{4}$ and $\mathrm{H}_{2}$.

$>$ The total amount of flammable gases formed in Voil is about 7.5 times smaller than in mineral oil MOL;

$>$ the coating with lacquer of the silicone steel sheet does not change the gas formation processes mechanism in the investigated oils;

$>$ the flammable gas formation process in $M O L$ is linearly in the first 700 hours of the thermal treatment followed by an acceleration of the process, while in the case of Voil, use the gases formation requires a start time of about 550 hours;

$>$ the oxygen content of the investigated oils decreases monotonous during the thermal treatment applied due to either the $\mathrm{CO}_{2}$ and $\mathrm{CO}$ formation and the oxidation processes of the investigated lacquers;

Acknowledgment: The work is performed under contract 30 PFE/2018 between National R\&D Institute for Electrical Engineering ICPE-CA and Romanian Ministry of Research and Innovation (MCI). Also, the authors acknowledge the financial support of MCI through the contract no. 100/2014 - UPMEE and Romanian Ministry of Research and Innovation (MCI) and the contract POC type D, No.11384/18.06.2018 ("ECONANO-ECO”).

\section{References}

1. SONALI, M. A., BANSIDHAR, E. K., Journal of Automation and Control, vol. 2 (2), 2014, p. 45-48.

2. SCATIGGIO, F., TUMiATTI, V., MAINA, R., TUMIATTI, M., POMPILI, M., BARTNIKAS, R., IEEE Transactions on Power Delivery, vol. 24 (3), 2009, p. 1240-1248.

3. MAINA, R., TUMIATTI, V., IEEE Transactions dielectrics and Electrical Insulation, vol. 16 (6), 2009, p. 1655-1663. 
4. WIKLUND, P., LEVIN; M., PAHLAVANPOUR, B., IEEE Electrical Insulation Magazine, vol. 23 (4), 2007, p. 6-14, DOI: 10.1109/ MEI.2007.386479,

5. MITREA, S., OPRINA, G., RADU, E., MARINESCU, V., VOINA, A., LINGVAY, I., Rev. Chim. (Bucharest), 67, no .9, 2016, p. 17071712.

6. VOINA, A., RADU, E., MITREA, S., OPRINA, G., LINGVAY, I., SERBAN, F., PICA, A., IEEExplore, 2016, p. 44-47, DOI: 10.1109/DEMISEE.2016.7530462

7. LingVAY, I., PATRU, I., UNGUREANU, L. C., STANOI, V., BORS, A. M., Rev. Chim. (Bucharest), 69, no.1, 2018, p. 91-95.

8. LINGVAY, I., UNGUREANU, L. C., STANOI, V., RUS, T., BORS, A. M., SZÁTMARI, I., OPRINA, G., Electrotehnica, Electronica, Automatica (EEA), vol. 65 (4), 2017, p. 117-122.

9. LINGVAY, I., RUS, T., BORS, A. M., STANOI, V., UNGUREANU, L. C., Electrotehnica, Electronica, Automatica (EEA), vol. 66 (3), 2018, p. 58-63.

10. LINGVAY, I., BORS, A. M., UNGUREANU, L. C., STANOI, V., RUS, T., Rev. Chim. (Bucharest), 69, no. 5, 2018 , p. $1139-1144$.

11. LUNGULESCU, E.M., LINGVAY, I., UNGUREANU, L.C., RUS, T., BORS, A. M., Mat. Plast, 55, no. 2, 2018, p. $201-206$.

12. RUS, T., CARAMITU, A. R., UNGUREANU, L. C., MARINESCU, V., BORS, A. M., VAIREANU, D. I., Mat. Plast, 55, no. 1, 2018, p. 28-32.

13. ***http://www.botosaniexpress.ro/flacari-uriase-si-explozii-in-lant-in-zona-industriala-mai-multe-transformatoare-electrice-au-luat-foc/

14. ***https://www.antena3.ro/actualitate/stare-de-alerta-explozii-in-lant-la-botosani-409657.html

15. LINGVAY, I., STANOI, V., UNGUREANU, L. C., LUCHIAN, A. M., OPRINA, G., Rev. Chim. (Bucharest), 69, no.7, 2018 , p. 1621-1627. 16. SABAU, J., STOCKHUYZEN, R., 2000 Annual Report Conference on Electrical Insulation and Dielectric Phenomena, Victoria, BC, Canada, vol. 1, October 2000, p. 264-267

17. LINGVAY, I., STANOI, V., UNGUREANU, L. C., SERBAN, F., BORS, A. M., Electrotehnica, Electronica, Automatica (EEA), vol. 65 (2), 2017, p. 23-30.

18. MARTIN, D., LELEKAKIS, N., WIJAYA, J., DUVAL, M., SAHA, T., IEEE Transactions on Power Delivery, vol. 29 (5), 2014 , p. 2369 2374.

19. CENNAMO, N., DE MARIA, L., D’AGOSTINO, G., ZENI, L., PESAVENTO, M., Sensors (Basel), vol. 15 (4), 2015 , p. $8499-8511$.

20. YUAN, Z., CHEN, M., LEI, H., LIN, C., Power and Energy Engineering Conference (APPEEC), IEEExplore, 2010, p. 1-3.

21. LINGVAY, I., UNGUREANU, L. C., OPRINA, G., STANOI, V., VOINA, A., PICA, A. A., Electrotehnica, Electronica, Automatica (EEA), vol. 65 (1), 2017, p. 62-66.

22. FOFANA, I., SABAU, J., BUSSIÈRES, D., ROBERTSON, E. B., Proceedings of the IEEE International Conference on Dielectric Liquids (ICDL '08), 2008, p. 1-4.

23. BORS, A. M., MEGHEA, I., MIHALY, M., MUNTEANU, C., BADEA, M., International Multidisciplinary Scientific GeoConference Surveying Geology and Mining Ecology Management, SGEM, vol. 1 (4), 2015, p. 533-540.

24. MEGHEA, I., BORS, A.G., MUNTEANU, G. V., MUNTEANU, C., BORS, A. M., International Multidisciplinary Scientific GeoConference Surveying Geology and Mining Ecology Management, SGEM, vol. 1, 2013, p. 1113-1120.

25. BORS, A. M., MEGHEA, I., NICOLESCU, A. M., BORS, A. G., 12th International Multidisciplinary Scientific GeoConference and EXPO - Modern Management of Mine Producing, Geology and Environmental Protection, SGEM, vol. 5, 2012, p. 891-898.

26. BORS, A. M., CIUCULESCU, C. A., MEGHEA, A., Rev. Chim. (Bucharest), 58, no.2, 2007, p. 151-157.

27. BORS,, A. M., MEGHEA, A., NEAMTU, S., LESNIC, M., Rev. Chim. (Bucharest), 58, no. 8, 2007, p. 776-781.

28. NEAMTU, S., BORS, A. M., STEFAN, S., Rev. Chim. (Bucharest), 58, no. 9, 2007, p. 938.

29. BORS, A. M., CIUCULESCU, C. A., MEGHEA, A., UPB Scientific Bulletin, Series B: Chemistry and Materials Science, vol. 68 (4), 2006 , p. 35-46.

30. FRIMPONG, G., PAGE, S., CARRANDER, K., CHERRY, D., ABB review, vol. 2 (12), 2012, p. 49-54.

31. LINGVAY, I., OPRINA, G., VOINA, A., BORS, A. M., UNGUREANU, L. C., Electrotehnica, Electronica, Automatica (EEA), vol. 66 (2), 2018, p. 31-36.

32. PERRIER, C., BEROUAL, A., IEEE Electrical Insulation Magazine, vol. 25 (6), 2009, p. 6-13.

33. CUCOS, A., BUDRUGEAC, P., LINGVAY, I., BORS, A. M., VOINA, A., Rev. Chim. (Bucharest), 69, no. 9, 2018 , p. $2366-2371$.

34. LINGVAY, I., OPRINA, G., UNGUREANU, L. C., PICA, A., STANOI, V., Rev. Chim. (Bucharest), 68, no. 12, 2017 , p. $2881-2885$.

35. LINGVAY, I., OPRINA, G., APOSTOL, E. S., LIPCINSKI, D., PATRU, I., MARINESCU, V., LUCHIAN, A. M., VAIREANU, D. I., Rev. Chim. (Bucharest), 69, no. 8, 2018, p. 2029-2034.

36. BORS, A. M., LINGVAY, D., CARAMITU, A. R., IORDACHE, I., LINGVAY, I., Mat. Plast., 56, no. 1, 2019, p. $129-132$.

37. BORS, A. M., LUNGULESCU, M. E., NICULA (BUTOI), N. O, CARAMITU, A. R., LINGVAY, I., Mat. Plast., 56, no. 2, 2019, p.330336.

38. WEESMAA, J., STERNER, M., PAHLAVANPOUR, B., BERGELD, L., NUNES, J., International Conference on Dielectric Liquids (ICDL), IEEExplore, 2014, p. 1-8.

39. BUDRUGEAC, P., LINGVAY, I., PICA, A., SBARCEA, B. G., Rev. Chim. (Bucharest), 68, no. 11, 2017, p. $2514-2518$

40. LINGVAY, I., BUDRUGEAC, P., VOINA, A., CUCOS, A., MOSCALIUC, H., Rev. Chim. (Bucharest), 67, no.11, 2016, p. $2202-2206$.

41. DEGERATU, S., ROTARU, P., RIZESCU, S., DANOIU, S., BIZDOACA, N. G., ALBOTEANU, L. I., MANOLEA, H. O., J. Therm. Anal. Calorim., vol. 119 (3), 2015, p. 1679-1692.

42. LINGVAY, I., BUDRUGEAC, P., UDREA, O., RADU, E., MARINESCU, M., Electrotehnică, Electronică, Automatică (EEA), vol. 63 (1), 2015, p. 64-70.

43.*** MOL TO - 30.01 R - mineral oil, electroinsulation, without additives, http://www.lubrifianti. com/produs/ transformator-897/mol-to-3001-r.html

44. LINGVAY, I., OPRINA, G., VOINA, A., PICA, A., SERBAN, F., STANOI, V., UNGUREANU, L. C., "Environmental-friendly electroinsulating fluid and obtaining process", Patent Application No. A / 00378 / 2017.

45. ***http://www.cesivo.ro/Lac-de-impregnare/Lac-de-impregnare-EZ528---4-Litri-372.html

46. STERE, E., POPA, I., BOTU, T. A., "Electroinsulating epoxydic varninish for glass threads and production method", patent RO 100096 (B1) 12. 29. 1987

47. *** https://www.ppgpmc.com/Products/7531/SIGMADUR-CLEARCOAT.aspx

Manuscript received: 31.10 .2019 